\title{
Penerapan Komunikasi Terapeutik Pada Pasien Skizofrenia Dalam Mengontrol Halusinasi Di RS Jiwa Menur Surabaya
}

\author{
Yosi Apriliani ${ }^{a}$, Esti Widiani ${ }^{\mathrm{a}}$ \\ aPoltekkes Kemenkes Malang (Kampus 2 Lawang), Jl. A.Yani Sumberporong Lawang, \\ Kabupaten Malang, 65212, Indonesia \\ e-mail korespondensi: yoshi.apriliani20@gmail.com, esti_widiani@poltekkes-malang.ac.id
}

\begin{abstract}
Hallucinations are absorption (perception) of the five senses without any stimulation from outside. The way to control hallucinations was by conducting therapeutic communication. Therapeutic communication is communication done by nurses during nursing interventions to help the patient's healing process and help patients overcome their problems through communication. Nurse's therapeutic communication has four phases of communication namely pre-interaction, orientation or introduction, work and termination. This study aims to improve the ability of people with schizophrenia in controlling hallucinations in Menur Mental Hospital Surabaya. The method in this research was a case study using two subjects. The results of this study indicate that after doing therapeutic communication with a frequency of 6 sessions in 6 days both subjects experienced an increase in the ability to control hallucinations. Therapeutic communication can improve the ability to control the hallucinations of the subject if it is done according to the stages.
\end{abstract}

Keywords: hallucinations, therapeutic communication, schizophrenia

\begin{abstract}
Abstrak
Halusinasi adalah penyerapan (persepsi) panca indra tanpa adanya rangsangan dari luar. Cara untuk mengontrol halusinasi adalah dengan melakukan komunikasi terapeutik. Komunikasi Terapeutik merupakan komunikasi yang dilakukan perawat pada saat melakukan intervensi keperawatan untuk membantu proses penyembuhan pasien dan membantu pasien mengatasi masalah yang dihadapinya melalui komunikasi. Komunikasi terapeutik perawat mempunyai empat fase komunikasi yaitu fase preinteraksi, orientasi atau perkenalan, kerja dan terminasi. Penelitian ini bertujuan untuk meningkatkan kemampuan pasien skizofrenia dalam mengontrol halusinasi di RS Jiwa Menur Surabaya. Metode dalam penelitian ini adalah studi kasus dengan menggunakan dua subjek. Hasil penelitian ini menunjukkan setelah dilakukannya komunikasi terapeutik dengan frekeunsi 6 sesi selama 6 hari kedua subjek mengalami peningkatan kemampuan dalam mengontrol halusinasi. Komunikasi terapeutik dapat meningkatkan kemampuan mengontrol halusinasi subjek jika dilakukan bertahap sesuai prosesdur yang bisa digunakan.
\end{abstract}

Kata kunci: halusinasi, komunikasi terapeutik, skizofrenia

\section{PENDAHULUAN}

Perkembangan yang pesat dalam berbagai bidang kehidupan manusia, yang meliputi bidang ekonomi, teknologi, sosial dan budaya serta bidang bidang yang lain telah membawa pengaruh yang besar bagi manusia itu sendiri. Kehidupan yang sulit dan komplek dengan meningkatnya kebutuhan menyebabkan bertambahnya stressor psikososial telah menyebabkan manusia tidak mampu menghindari tekanan-tekanan hidup yang dialami. Kondisi kritis ini membawa dampak terhadap peningkatan kualitas maupun kuantitas penyakit mental-emosional manusia (Yusuf et al., 2015). Merujuk data hasil Riset Kesehatan Dasar (Riskesdas) tahun 2018 bahwa prevalensi rumah tangga dengan anggota yang menderita skizofrenia atau psikosis sebesar 7 per 1000 dengan cakupan 
pengobatan 84,9 persen (Kemenkes RI, n.d.). Psikosis ada dua jenis yaitu psikosis organik, dimana didapatkan kelainan pada otak dan psikosis fungsional, tidak terdapat kelainan pada otak. Psikosis sebagai salah satu bentuk gangguan jiwa merupakan ketidakmampuan untuk berkomunikasi atau mengenali realitas yang menimbulkan kesukaran dalam kemampuan seseorang untuk berperan sebagaimana mestinya dalam kehidupan sehari-hari. Tanda dan gejala psikosis antara lain : perilaku regresi, perasaan tidak sesuai, berkurangnya pengawasan-pengawasan terhadap impuls-impuls, waham dan halusinasi. Pengobatan pada psikosis adalah neuroleptik misalnya Chlorpromazine yang diberikan secara intra muscular, Trannquilaizer misalnya Valium atau Stesolid yang diberikan secara intra vena. Sedangkan terapi oral yang diberikan pada psikosis adalah Triflouperazine (Stelazine) dan Haloperidol (Direja, 2011).

Salah satu gejala psikosis yang dialami penderita gangguan jiwa adalah halusinasi yang merupakan gangguan persepsi dimana klien mempersepsikan sesuatu yang sebenarnya tidak terjadi (Stuart, 2013). Halusinasi merupakan persepsi sensorik penglihatan, sentuh, pendengaran, penghidu/pengecap tanpa rangsang luar. Tindakan pengobatan yang dapat dilakukan kepada klien dengan halusinasi yaitu pengobatan psikofarmaka dan terapi kejang listrik (Direja, 2011). Tindakan keperawatan yang dapat diberikan yaitu terapi modalitas yang meliputi terapi individu, terapi lingkungan, terapi kognitif, terapi kelompok terapi perilaku dan terapi keluarga melalui komunikasi (Keliat \& Prawirowiyono, 2016).

Pelayanan keperawatan yang diberikan kepada klien terutama dengan halusinasi, yaitu klien diberikan pengobatan psikofarmaka dan terapi modalitas keperawatan (terapi aktivitas kelompok, terapi rekreasi, terapi lingkungan, terapi individu dan terapi okupasi). Terapi individu merupakan salah satu bentuk terapi yang dilakukan secara individu oleh perawat kepada klien secara tatap muka perawat-klien dengan durasi waktu tertentu sesuai dengan tujuan yang ingin dicapai (Yusuf et al., 2015). Pelaksanaannya adalah dengan menggunakan komunikasi terapeutik yang dilakukan perawat dengan pasien yang mempunyai tujuan yaitu klien mampu mengontrol halusinasi. Dengan teknik komunikasi terapeutik ini berguna untuk membangun hubungan terapeutik perawat dan klien, mengidentifikasi masalah klien, mengkaji persepsi klien tentang masalah yang dihadapinya. Teknik komunikasi terapeutik merupakan salah satu teknik dalam proses penyembuhan pasien terutama dengan masalah keperawatan gangguan jiwa tak terkecuali pasien gangguan jiwa dengan halusinasi (Stuart, 2013).

Berdasarkan fenomena di atas pasien dengan halusinasi merupakan kategori 10 besar diagnosa prioritas dan dominan persentase terbanyak jumlah pasien dengan diagnosa halusinasi dibandingkan dengan diagnosa lainnya di RS Jiwa Menur Surabaya sehingga penulis tertarik untuk mengadakan penelitian untuk mengetahui bagaimanakah kemampuan pasien skizofrenia dalam mengontrol halusinasi sebelum dan sesudah dilakukannya komunikasi terapeutik. Sehingga dengan ini penulis mengambil judul Kemampuan Pasien Skizofrenia dalam Mengontrol Halusinasi di RS Jiwa Menur Surabaya.

\section{METODE}

Penelitian ini merupakan rancangan studi kasus. Populasi dalam penelitian ini adalah pasien dengan diagnosa medis skizofrenia yang dirawat di RS. Menur Surabaya. Subjek dari penelitian ini adalah 2 (dua) pasien skizofrenia yang berdasarkan pengkajian memiliki halusinasi serta memenuhi kriteria inklusi dan eksklusi yang telah ditetapkan. Kriteria inklusinya adalah pasien pria maupun wanita yang dirawat di RSJ Menur Surabaya yang telah dilakukan pengkajian keperawatan dengan masalah utama keperawatan halusinasi. Kriteria eksklusinya adalah pasien yang mengalami kesulitan dalam berkomunikasi. Fokus studi kasus pada penelitian ini adalah untuk 
mengetahui kemampuan pasien skizofrenia dalam mengontrol halusinasi setelah diberikan komunikasi terapeutik. Instrumen yang digunakan untuk mengumpulkan data adalah lembar wawancara pre post test untuk mengetahui kemampuan pasien mengenali dan mengontrol halusinasi yang dibuat oleh peneliti, lembar observasi harian untuk mengetahui kemampuan pasien mengenali dan mengontrol halusinasi yang dibuat oleh peneliti, standart operating proccedur (SOP) komunikasi terapeutik yang dibuat oleh peneliti dan alat perekam wawancara menggunakan gawai pintar.

Kegiatan pengambilan data dilakukan selama 6 (enam) hari. Peneliti bekerja sama dengan pihak perawat RS Jiwa Menur Surabaya dalam penerapan komunikasi terapeutik pada pasien halusinasi, peneliti mengidentifikasi kemampuan pasien mengontrol halusinasi sebelum dan sesudah dilakukan komunikasi terapeutik oleh peneliti. Komunikasi terapeutik kepada subjek dilakukan selama 6 hari sesuai pedoman SOP komunikasi terapeutik, setiap harinya dilakukan sebanyak 1 kali sesi pada pagi selama 20-30 menit setiap kali.

Data yang terkumpul berupa lembar wawancara pre test, lembar penilaian pelaksanaan komunikasi terapeutik dan lembar observasi harian respon kemampuan pasien serta lembar wawancara post test dikumpulkan untuk dianalisa dengan mengambil kesimpulan serta dinarasikan oleh peneliti.

\section{HASIL}

\section{Gambaran Subjek Penelitian}

Subjek studi kasus pertama (I) adalah subjek berusia 50 tahun beragama Islam dengan tingkat pendidikan terakhir S1. Subjek I tinggal sebelum sakit tinggal bersama suami dan ketiga anaknya namun semenjak sering kambuh akhirnya subjek di titipkan di rumah adiknya di Surabaya untuk memudahkan pengobatan. Subjek bekerja sebagai guru disalah satu pondok pesantren, dan suaminya bekerja sebagai sopir dan jarang pulang. Subjek dirawat di RS Jiwa Menur Surabaya di Ruang Flamboyan. Berdasarkan hasil wawancara yang didapatkan, menurut subjek beliau di rawat di RS Jiwa karena subjek mengamuk kepada adiknya karena subjek merasa melihat adiknya seperti melihat monster.

Subjek studi kasus yang kedua (II) berusia 44 tahun beragama Islam dengan tingkat pendidikan terakhir SMA. Subjek II tinggal bersama ibunya, karena sudah diceraikan oleh suaminya setelah 1 (satu) minggu pernikahannya. Subjek anak pertama dari 3 bersaudara. Pekerjaan subjek yaitu berjualan sembako di depan rumahnya di bantu oleh ibunya. Dari hasil wawancara yang didapat, subjek dirawat di RS Jiwa Menur Surabaya karena kambuh, teriak-teriak dan berhalusinasi

\section{Pemaparan Fokus Studi Kasus}

A. Hasil Wawancara Pre dan Post Test Untuk Mengetahui Kemampuan Pasien Dalam Mengenali Dan Mengontrol Halusinasi

Kunjungan pertama di RS Jiwa Menur Surabaya peneliti mendatangi Ruang Flamboyan untuk melakukan wawancara pre test. Peneliti memberikan penjelasan maksud dan tujuan dari penelitian sebelum melakukan pre test. Hasil wawancara pre test pada subjek I dan subjek II disajikan dalam tabel 1 dan 2.

Tabel 1. Hasil Wawancara Pre test pada Subjek I

\begin{tabular}{|c|l|l|}
\hline No & \multicolumn{1}{|c|}{ Pertanyaan } & \multicolumn{1}{c|}{ Tanggapan } \\
\hline 1 & $\begin{array}{l}\text { Bagaimana kabar } \\
\text { bapak/ibu hari ini? }\end{array}$ & $\begin{array}{l}\text { "Alhamdulillah baik } \\
\text { mbak " }\end{array}$ \\
\hline 2 & $\begin{array}{l}\text { Apakah bapak/ibu } \\
\text { bisa menjelaskan } \\
\text { tentang halusinasi } \\
\text { yang dialami? }\end{array}$ & $\begin{array}{l}\text { "Bisa, halusinasi saya } \\
\text { itu banyak mbak ada } \\
\text { wahamnya juga" }\end{array}$ \\
\hline 3 & $\begin{array}{l}\text { Halusinasi apa } \\
\text { yang sedang } \\
\text { bapak/ibu alami? }\end{array}$ & $\begin{array}{l}\text { "pendengaran, } \\
\text { penglihatan, perasa, } \\
\text { dan penciuman juga } \\
\text { pokoknya buanyak" } \\
\text { kalau waham saya kata } \\
\text { mbaknya itu waham } \\
\text { kebesaran mbak" }\end{array}$ \\
\hline
\end{tabular}


NERS: Jurnal Keperawatan, Volume 16, No. 2, Oktober 2020, (Hal. 61-74)

\begin{tabular}{|c|c|c|}
\hline 4 & $\begin{array}{l}\text { Seperti apa isi } \\
\text { halusinasi tersebut? }\end{array}$ & $\begin{array}{l}\text { "kalau pendengaran } \\
\text { saya seperti mendengar } \\
\text { suara orang menyuruh } \\
\text { wiritan kalau gak } \\
\text { wiritan berarti sudah } \\
\text { mati saya, kalau } \\
\text { penglihatan saya } \\
\text { melihat disekitar saya } \\
\text { itu nabi, malaikat, } \\
\text { bidadari, monster" }\end{array}$ \\
\hline 5 & $\begin{array}{l}\text { Kapan halusinasi } \\
\text { itu muncul? }\end{array}$ & $\begin{array}{l}\text { "Sewaktu-waktu } \\
\text { mbak" }\end{array}$ \\
\hline 6 & $\begin{array}{l}\text { Berapa lama } \\
\text { frekuensi } \\
\text { halusinasi itu } \\
\text { muncul? }\end{array}$ & $\begin{array}{l}\text { " tidak ngukur saya, } \\
\text { kira-kira ya sekilas } \\
\text { gitu" }\end{array}$ \\
\hline 7 & $\begin{array}{l}\text { Bagaimana } \\
\text { perasaan bapak/ibu } \\
\text { saat halusinasi itu } \\
\text { muncul? }\end{array}$ & $\begin{array}{l}\text { "biasa saya mbak, toh } \\
\text { ya sudah sering dulu } \\
\text { dari saya SMA" }\end{array}$ \\
\hline 8 & $\begin{array}{l}\text { Apa yang } \\
\text { dilakukan ketika } \\
\text { halusinasi muncul? }\end{array}$ & $\begin{array}{l}\text { "kalau suara yang } \\
\text { muncul saya jawab } \\
\text { mbak (saya ladeni) } \\
\text { kalau penglihatan pas } \\
\text { lihat monster saya } \\
\text { teriak ketakutan" }\end{array}$ \\
\hline 9 & $\begin{array}{l}\text { Apakah dengan } \\
\text { menghardik } \\
\text { halusinasi hilang? }\end{array}$ & $\begin{array}{l}\text { " menghardik itu yang } \\
\text { gimana ya mbak,saya } \\
\text { lupa" }\end{array}$ \\
\hline 10 & $\begin{array}{l}\text { Apakah dengan } \\
\text { banyak kegiatan } \\
\text { halusinasi } \\
\text { berkurang? }\end{array}$ & "sepertinya begitu" \\
\hline 11 & $\begin{array}{l}\text { Apakah bercakap } \\
\text { dengan teman } \\
\text { dapat } \\
\text { menghilangkan } \\
\text { halusinasi }\end{array}$ & $\begin{array}{l}\text { " nggak mesti, kadang } \\
\text { masih muncul kalau } \\
\text { saya lagi bicara sama } \\
\text { orang" }\end{array}$ \\
\hline 12 & $\begin{array}{l}\text { Apakah rutin } \\
\text { minum obat } \\
\text { halusinasi hilang? }\end{array}$ & $\begin{array}{l}\text { "iya mbak, kalau nggak } \\
\text { minum duhh saya } \\
\text { sudah kambuh lagi } \\
\text { mbak" }\end{array}$ \\
\hline
\end{tabular}

cara menanggapi ketika halusinasi muncul dan mengatasi kekambuhannya. Disamping itu halusinasi yang dialami subjek I bermacam-macam sehingga diperlukan komunikasi terapeutik untuk menangani halusinasinya.

Tabel 2. Hasil Wawancara Pre Test Subjek

II

\begin{tabular}{|c|c|c|}
\hline No & Pertanyaan & Tanggapan \\
\hline 1 & $\begin{array}{l}\text { Bagaimana kabar } \\
\text { bapak/ibu hari ini? }\end{array}$ & "baik" \\
\hline 2 & $\begin{array}{l}\text { Apakah bapak/ibu } \\
\text { bisa menjelaskan } \\
\text { tentang halusinasi } \\
\text { yang dialami? }\end{array}$ & $\begin{array}{l}\text { "saya tidak } \\
\text { halusinasi" }\end{array}$ \\
\hline 3 & $\begin{array}{l}\text { Halusinasi apa } \\
\text { yang sedang } \\
\text { bapak/ibu alami? }\end{array}$ & "tidak tahu' \\
\hline 4 & $\begin{array}{l}\text { Seperti apa isi } \\
\text { halusinasi tersebut? }\end{array}$ & $\begin{array}{l}\text { "rambut saya ditarik- } \\
\text { tarik, saya disuruh } \\
\text { nulis" }\end{array}$ \\
\hline 5 & $\begin{array}{l}\text { Kapan halusinasi } \\
\text { itu muncul? }\end{array}$ & "tidak tahu" \\
\hline 6 & $\begin{array}{l}\text { Berapa lama } \\
\text { frekuensi } \\
\text { halusinasi itu } \\
\text { muncul? }\end{array}$ & "tidak tahu" \\
\hline 7 & $\begin{array}{l}\text { Bagaimana } \\
\text { perasaan bapak/ibu } \\
\text { saat halusinasi itu } \\
\text { muncul? }\end{array}$ & " tidak tahu" \\
\hline 8 & $\begin{array}{l}\text { Apa yang } \\
\text { dilakukan ketika } \\
\text { halusinasi muncul? }\end{array}$ & $\begin{array}{l}\text { "saya nangis, sakit } \\
\text { rambut saya ditarik" }\end{array}$ \\
\hline 9 & $\begin{array}{l}\text { Apakah dengan } \\
\text { menghardik } \\
\text { halusinasi hilang? }\end{array}$ & $\begin{array}{l}\text { "apa menghardik itu } \\
\text { mbak" }\end{array}$ \\
\hline 10 & $\begin{array}{l}\text { Apakah dengan } \\
\text { banyak kegiatan } \\
\text { halusinasi } \\
\text { berkurang? }\end{array}$ & "tidak tau" \\
\hline 11 & $\begin{array}{l}\text { Apakah bercakap } \\
\text { dengan teman } \\
\text { dapat } \\
\text { menghilangkan } \\
\text { halusinasi }\end{array}$ & $\begin{array}{l}\text { "saya tidak punya } \\
\text { teman" }\end{array}$ \\
\hline
\end{tabular}
subjek I didapatkan subjek mengutarakan jawaban yang menggambarkan masalah subjek, yaitu subjek belum mengetahui frekuensi halusinasi dan tidak tahu bagaimana 
NERS: Jurnal Keperawatan, Volume 16, No. 2, Oktober 2020, (Hal. 61-74)

\begin{tabular}{|c|l|l|}
\hline 12 & $\begin{array}{l}\text { Apakah rutin } \\
\text { minum obat } \\
\text { halusinasi hilang? }\end{array}$ & $\begin{array}{l}\text { "saya bosan obat, } \\
\text { pengen pulang" }\end{array}$ \\
\hline
\end{tabular}

Subjek II mengutarakan jawaban yang menggambarkan masalahnya, yaitu subjek belum mampu mengenali jenis halusinasinya, cara mengontrol halusinasinya, subjek beranggapan itu bukan halusinasi karena subjek dulunya pernah dirawat di RSJ Menur dengan Harga Diri Rendah. Sehingga komunikasi terapeutik tepat dilakukan kepada subjek II yang baru merasakan halusinasi untuk membantu subjek mengenali dan mengontrol halusinasinya.

Setelah mendapatkan kesimpulan dari lembar wawancara pre-test subjek I dan II yang sesuai dengan kriteria inklusi, kemudian peneliti menjelaskan komunikasi terapeutik dapat membatu mengenali jenis halusinasi dan meningkatkan kemampuan dalam mengontrol halusinasi. Setelah subjek paham dan mengerti kemudian menandatangani lembar Inform Consent sebagai tanda bukti bahwa subjek penelitian telah setuju untuk berpartisipasi dalam penelitian.

Kemudian, peneliti membuat kontrak waktu bersama subjek, peneliti menjelaskan komunikasi ini akan dilakukan selama 6 hari setiap harinya dimana setiap sesi berlangsung sekitar 30 - 40 menit. Selanjutnya, peneliti bekerja sama dengan enumerator menyamakan persepsi tentang pelaksanaan kegiatan. Selanjutnya peneliti bersama enumerator dalam tahap penerapannya dan mengobservasi dan meneliti hasil sesi. Enumerator dalam penelitian ini berjumlah satu orang. Enumerator merupakan perawat yang bekerja di ruang Flamboyan RS Jiwa Menur Surabaya. Enumerator terlebih dahulu menyamakan persepsi bersama peneliti dengan melakukan penilaian penerapan tahapan komunikasi terapeutik terhadap pasien berdasarkan format yang dibuat oleh peneliti.

Berikut ini adalah hasil wawancara post test sesudah subjek I dan II dilakukan penerapan komunikasi terapeutik yang disajikan pada tabel 3 dan 4 .
Tabel 3. Hasil Wawancara Post test Subjek I

\begin{tabular}{|c|c|c|}
\hline No & Pertanyaan & Tanggapan \\
\hline 1 & $\begin{array}{l}\text { Bagaimana kabar } \\
\text { bapak/ibu hari ini? }\end{array}$ & $\begin{array}{l}\text { " alhamdulillah sudah } \\
\text { baik mbak" }\end{array}$ \\
\hline 2 & $\begin{array}{l}\text { Apakah bisa } \\
\text { menjelaskan } \\
\text { tentang halusinasi } \\
\text { yang dialami? }\end{array}$ & $\begin{array}{l}\text { " bisa mbak,sudah } \\
\text { paham saya " }\end{array}$ \\
\hline 3 & $\begin{array}{l}\text { Halusinasi apa } \\
\text { yang sedang } \\
\text { bapak/ibu alami? }\end{array}$ & $\begin{array}{l}\text { " saya halusinasi } \\
\text { pendengaran, } \\
\text { penglihatan disertai } \\
\text { waham juga mbak" }\end{array}$ \\
\hline 4 & $\begin{array}{l}\text { Seperti apa isi } \\
\text { halusinasi tersebut? }\end{array}$ & 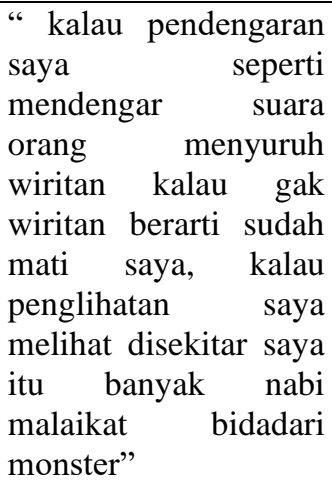 \\
\hline 5 & $\begin{array}{l}\text { Kapan halusinasi } \\
\text { itu muncul? }\end{array}$ & $\begin{array}{l}\text { " halusinasi itu } \\
\text { munculnya setiap } \\
\text { setelah selesai adzan } \\
\text { sholat, tapi sekarang } \\
\text { sudah berkurang kan } \\
\text { saya sudah tau caranya } \\
\text { " }\end{array}$ \\
\hline 6 & $\begin{array}{l}\text { Berapa lama } \\
\text { frekuensi } \\
\text { halusinasi itu } \\
\text { muncul? }\end{array}$ & $\begin{array}{l}\text { " dulu lama mbak, } \\
\text { kalau sekarang hanya } \\
\text { sekilas saja.. sudah } \\
\text { jarang pokoknya" }\end{array}$ \\
\hline 7 & $\begin{array}{l}\text { Bagaimana } \\
\text { perasaan bapak/ibu } \\
\text { saat halusinasi itu } \\
\text { muncul? }\end{array}$ & $\begin{array}{l}\text { " kalau perasaan saya } \\
\text { tetap biasa-biasa saja } \\
\text { kok mbak tidak takut } \\
\text { saya" }\end{array}$ \\
\hline 8 & $\begin{array}{l}\text { Apa yang } \\
\text { dilakukan ketika } \\
\text { halusinasi muncul? }\end{array}$ & $\begin{array}{l}\text { "saya terapkan yang } \\
\text { sudah diajarkan mbak } \\
\text { sebelumnya, seperti } \\
\text { menghardik, } \\
\text { menyibukkan diri dan } \\
\text { yang penting minum } \\
\text { obat teratur" }\end{array}$ \\
\hline 9 & $\begin{array}{l}\text { Apakah dengan } \\
\text { menghardik } \\
\text { halusinasi hilang? }\end{array}$ & $\begin{array}{l}\text { "iya mbak langsung } \\
\text { pergi halusinasinya" }\end{array}$ \\
\hline
\end{tabular}


NERS: Jurnal Keperawatan, Volume 16, No. 2, Oktober 2020, (Hal. 61-74)

\begin{tabular}{|c|c|c|}
\hline 10 & $\begin{array}{l}\text { Apakah dengan } \\
\text { banyak kegiatan } \\
\text { halusinasi } \\
\text { berkurang? }\end{array}$ & $\begin{array}{l}\text { " iya mbak, pokoknya } \\
\text { nggak ngelamun gitu } \\
\text { ya aman" }\end{array}$ \\
\hline 11 & $\begin{array}{l}\text { Apakah bercakap } \\
\text { dengan teman } \\
\text { dapat } \\
\text { menghilangkan } \\
\text { halusinasi }\end{array}$ & 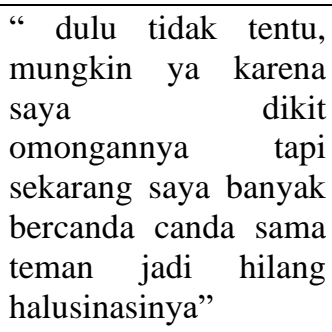 \\
\hline 12 & $\begin{array}{l}\text { Apakah rutin } \\
\text { minum obat } \\
\text { halusinasi hilang? }\end{array}$ & $\begin{array}{l}\text { " hilang mbak, kalau } \\
\text { gak minum sudah pasti } \\
\text { saya kumat lagi mbak" }\end{array}$ \\
\hline 13 & $\begin{array}{l}\text { Dan bagaimana } \\
\text { halusinasi } \\
\text { bapak/ibu saat ini, } \\
\text { berkurang atau } \\
\text { bertambah? }\end{array}$ & $\begin{array}{l}\text { "alhamdulillah } \\
\text { berkurang sudah " }\end{array}$ \\
\hline 14 & $\begin{array}{l}\text { Apakah } \\
\text { komunikasi yang } \\
\text { sudah dilakukan } \\
\text { dapat membantu? }\end{array}$ & $\begin{array}{l}\text { "iya mbak, sangat } \\
\text { membantu sekali " }\end{array}$ \\
\hline
\end{tabular}

Berdasarkan hasil wawancara posttest subjek 1 mengutarakan jawaban yang menggambarkan kemampuan subjek, yaitu subjek sudah mampu mengenali halusinasinya, mampu mengontrol halusinasi, menerapkan pelaksanaan setiap sesi komunikasi terapeutik. Sehingga subjek sudah mengetahui apa yang harus dilakukan ketika halusinasi muncul serta mengatasi kekambuhan. Dapat disimpulkan dengan adanya komunikasi terapeutik yang dilakukan secara bertahap sesuai dengan Standar Operasional Prosedur dapat meningkatkan kemampuan pasien skizofrenia dalam mengontrol halusinasi serta mengurangi frekuensi munculnya halusinasi.
Tabel 4. Hasil Wawancara Post test Subjek II

\begin{tabular}{|c|c|c|}
\hline No & Pertanyaan & Tanggapan \\
\hline 1 & $\begin{array}{l}\text { Bagaimana kabar } \\
\text { bapak/ibu hari ini? }\end{array}$ & $\begin{array}{l}\text { "Sudah baik saya } \\
\text { mbk, pengen pulang " }\end{array}$ \\
\hline 2 & $\begin{array}{l}\text { Apakah bisa } \\
\text { menjelaskan } \\
\text { tentang halusinasi } \\
\text { yang dialami? }\end{array}$ & "bisa lah" \\
\hline 3 & $\begin{array}{l}\text { Halusinasi apa } \\
\text { yang sedang } \\
\text { bapak/ibu alami? }\end{array}$ & $\begin{array}{l}\text { "halusinasi } \\
\text { pendengaran, sama } \\
\text { penglihatan" }\end{array}$ \\
\hline 4 & $\begin{array}{l}\text { Seperti apa isi } \\
\text { halusinasi } \\
\text { tersebut? }\end{array}$ & $\begin{array}{l}\text { "Rambut saya seperti } \\
\text { ditarik-tarik orang tapi } \\
\text { nggak ada orangnya, } \\
\text { trus saya itu dibisiki } \\
\text { orang disuruh belajar } \\
\text { nulis " }\end{array}$ \\
\hline 5 & $\begin{array}{l}\text { Kapan halusinasi } \\
\text { itu muncul? }\end{array}$ & $\begin{array}{l}\text { "Halusinasi saya } \\
\text { muncul ya pas kalau } \\
\text { saya melamun,saya } \\
\text { tiduran dikasur" }\end{array}$ \\
\hline 6 & $\begin{array}{l}\text { Berapa lama } \\
\text { frekuensi } \\
\text { halusinasi itu } \\
\text { muncul? }\end{array}$ & $\begin{array}{l}\text { "ya enggak terlalu } \\
\text { sering " }\end{array}$ \\
\hline 7 & $\begin{array}{l}\text { Bagaimana } \\
\text { perasaan bapak/ibu } \\
\text { saat halusinasi itu } \\
\text { muncul? }\end{array}$ & $\begin{array}{l}\text { “ya takut mbk, tapi } \\
\text { lama-lama udah biasa } \\
\text { “ }\end{array}$ \\
\hline 8 & $\begin{array}{l}\text { Apa yang } \\
\text { dilakukan ketika } \\
\text { halusinasi muncul? }\end{array}$ & $\begin{array}{l}\text { "saya lebih sering } \\
\text { berkegiatan mbk, yang } \\
\text { penting nggak diem, } \\
\text { tapi ya kalau capek } \\
\text { saya hardik seperti } \\
\text { yang mbk ajarkan" }\end{array}$ \\
\hline 9 & $\begin{array}{l}\text { Apakah dengan } \\
\text { menghardik } \\
\text { halusinasi hilang? }\end{array}$ & " iya mbk " \\
\hline 10 & $\begin{array}{l}\text { Apakah dengan } \\
\text { banyak kegiatan } \\
\text { halusinasi } \\
\text { berkurang? }\end{array}$ & " betul sekali " \\
\hline 11 & $\begin{array}{l}\text { Apakah bercakap } \\
\text { dengan teman } \\
\text { dapat }\end{array}$ & " iya mbk" \\
\hline
\end{tabular}


NERS: Jurnal Keperawatan, Volume 16, No. 2, Oktober 2020, (Hal. 61-74)

\begin{tabular}{|c|l|l|}
\hline & $\begin{array}{l}\text { menghilangkan } \\
\text { halusinasi }\end{array}$ & \\
\hline 12 & $\begin{array}{l}\text { Apakah rutin } \\
\text { minum obat } \\
\text { halusinasi hilang? }\end{array}$ & " iya mbk" \\
\hline 13 & $\begin{array}{l}\text { Dan bagaimana } \\
\text { halusinasi } \\
\text { bapak/ibu saat ini, } \\
\text { berkurang atau } \\
\text { bertambah? }\end{array}$ & $\begin{array}{l}\text { "sudah berkurang ini } \\
\text { tidak separah dulu " }\end{array}$ \\
\hline 14 & $\begin{array}{l}\text { Apakah } \\
\text { komunikasi yang } \\
\text { sudah dilakukan } \\
\text { dapat membantu? }\end{array}$ & $\begin{array}{l}\text { membantu saya jadi } \\
\text { tau gimana caranya " }\end{array}$ \\
\hline
\end{tabular}

\begin{tabular}{|c|c|c|c|c|c|c|c|c|}
\hline 2 & $\begin{array}{l}\text { Mengenal isi } \\
\text { halusinasi }\end{array}$ & $\checkmark$ & $\checkmark$ & $\checkmark$ & $\checkmark$ & $\checkmark$ & $\checkmark$ & $\checkmark$ \\
\hline 3 & $\begin{array}{l}\text { Mengenal } \\
\text { waktu } \\
\text { halusinasi }\end{array}$ & $x$ & $\checkmark$ & $\checkmark$ & $\checkmark$ & $\checkmark$ & $\checkmark$ & $\checkmark$ \\
\hline 4 & $\begin{array}{l}\text { Mengenal } \\
\text { frekuensi } \\
\text { halusinasi } \\
\end{array}$ & $x$ & $\checkmark$ & $\checkmark$ & $\checkmark$ & $\checkmark$ & $\checkmark$ & $\checkmark$ \\
\hline 5 & $\begin{array}{l}\text { Mengenal } \\
\text { situasi yang } \\
\text { menimbulkan } \\
\text { halusinasi }\end{array}$ & $x$ & $\checkmark$ & $\checkmark$ & $\checkmark$ & $\checkmark$ & $\checkmark$ & $\checkmark$ \\
\hline 6 & $\begin{array}{l}\text { Menjelaskan } \\
\text { respon } \\
\text { terhadap } \\
\text { halusinasi }\end{array}$ & $\checkmark$ & $\checkmark$ & $\checkmark$ & $\checkmark$ & $\checkmark$ & $\checkmark$ & $\checkmark$ \\
\hline 7 & $\begin{array}{l}\text { Mampu } \\
\text { menghardik } \\
\text { halusinasi }\end{array}$ & $\times$ & $x$ & $\checkmark$ & $\checkmark$ & $\checkmark$ & $\checkmark$ & $\checkmark$ \\
\hline 8 & $\begin{array}{l}\text { Mampu } \\
\text { bercakap- } \\
\text { cakap jika } \\
\text { terjadi } \\
\text { halusinasi }\end{array}$ & $x$ & $x$ & $x$ & $\checkmark$ & $\checkmark$ & $\checkmark$ & $\checkmark$ \\
\hline 9 & $\begin{array}{l}\text { Membuat } \\
\text { jadwal } \\
\text { kegiatan } \\
\text { harian }\end{array}$ & $x$ & $x$ & $x$ & $x$ & $\checkmark$ & $\checkmark$ & $\checkmark$ \\
\hline 10 & $\begin{array}{l}\text { Melakukan } \\
\text { kegiatan } \\
\text { harian sesuai } \\
\text { jadwal }\end{array}$ & $x$ & $x$ & $x$ & $x$ & $x$ & $\checkmark$ & $\checkmark$ \\
\hline 11 & $\begin{array}{l}\text { Menggunakan } \\
\text { obat secara } \\
\text { teratur }\end{array}$ & $\checkmark$ & $\checkmark$ & $\checkmark$ & $\checkmark$ & $\checkmark$ & $\checkmark$ & $\checkmark$ \\
\hline
\end{tabular}

Berdasarkan hasil wawancara post-test subjek 2 mengutarakan jawaban yang menggambarkan kemampuan subjek, yaitu subjek sudah mampu mengenali halusinasinya, mampu mengontrol halusinasi, menerapkan pelaksanaan setiap sesi komunikasi terapeutik. Sehingga subjek sudah mengetahui apa yang harus dilakukan ketika halusinasi muncul. Dapat disimpulkan dengan adanya komunikasi terapeutik yang dilakukan secara bertahap sesuai dengan standar prosedur operasional dapat meningkatkan kemampuan pasien skizofrenia dalam mengontrol halusinasi.

\section{B. Hasil Observasi Harian Untuk Mengetahui Kemampuan Pasien dalam Mengontrol Halusinasi}

Peneliti melakukan observasi saat penerapan komunikasi terapeutik selama 6 hari. Hasil observasi pada subjek I dan II disajikan dalam tabel berikut ini

Tabel 5. Hasil Observasi Harian Subjek I

\begin{tabular}{|c|l|c|c|c|c|c|c|c|}
\hline \multirow{2}{*}{ No } & \multirow{2}{*}{ Kemampuan } & \multicolumn{7}{|c|}{ Hari } \\
\cline { 3 - 8 } & $\mathbf{1}$ & $\mathbf{2}$ & $\mathbf{3}$ & $\mathbf{4}$ & $\mathbf{5}$ & $\mathbf{6}$ & $\mathbf{7}$ \\
\hline 1 & $\begin{array}{l}\text { Mengenal } \\
\text { jenis } \\
\text { halusinasi }\end{array}$ & $\checkmark$ & $\checkmark$ & $\checkmark$ & $\checkmark$ & $\checkmark$ & $\checkmark$ & $\checkmark$ \\
\hline
\end{tabular}

Observasi hari 1 subjek I mengutarakan masalahnya dengan pertanyaan apa, dimana, kapan, siapa, dan bagaimana. Selain itu subjek dapat menyebutkan masalah yang dirasakan, serta dapat mengutarakan pikiran dan memberikan tanggapan dengan rasional, selain itu subjek juga tampak senang dan adanya kontak mata. Kemudian didapatkan hasil pikiran otomatis subjek 1 adalah subjek meyakini bahwa memang berhalusinasi dan mengetahui jenis serta waktu munculnya halusinasi tetapi untuk frekuensi halusinasi subjek mengatakan belum mengukurnya.

Observasi hari 2 subjek dapat mengutarakan apa yang dibahas ketika sesi 1 yaitu mengidentifikasi halusinasi yang dialami subjek. Kemudian subjek dapat menyebutkan frekuensi muncul halusinasi yaitu sehari 5 kali setelah adzan sholat dan

Yosi Apriliani, dkk., Penerapan Komunikasi Terapeutik Pada,... 
sebentar. Kemudian peneliti melanjutkan strategi pelaksanaan II yaitu tentang mengontrol halusinasi dengan cara menghardik. Pada sebelumnya saat pre-test subjek mengaku lupa apa itu menghardik, sehingga peneliti menjelaskan kembali pengertian dan cara-cara menghardik. Subjek dapat memahami dan mampu menirukan atau mengulangi cara-cara yang sudah diajarkan, subjek juga mengutarakan perasaan senangnya. Peneliti menulis peningkatan kemampuan subjek tersebut dan membuat rencana tindak lanjut latihan menghardik untuk di evaluasi pada sesi berikutnya.

Observasi hari 3, pada evaluasi menghardik subjek mengatakan sudah mampu menerapkannya saat halusinasi muncul. Kemudian dilanjutkan strategi pelaksanaan III, setelah dilakukan sesi bercakap-cakap subjek bersama temannya diperoleh subjek dapat berdiskusi serta mampu memulai atau mengawali pembicaraan. Kemudian subjek dapat mengungkapkan keinginannya bahwa subjek ingin berinteraksi bersama siapa pun tanpa ada batasan. Kemudian subjek dikenalkan metode membuat jadwal mengisi waktu luang atau kegiatan harian dan akan dibahas pada sesi berikutnya.

Observasi hari 4, sebelum lanjut ke sesi 4 peneliti menanyakan bagaimana perkembangan bercakap-cakap bersama teman subjek mengatakan sudah menerapkan dengan baik. Kemudian selanjutnya dilakukannya strategi pelaksanaan 4 bersama subjek diperoleh subjek dapat membuat jadwal kegiatan sehari-hari untuk dijadikan sebagai aktivitas sehingga halusinasi dapat terkontrol.

Observasi hari 5, peneliti mengevaluasi aktivitas subjek sudah sesuai dengan jadwal yang dibuat pada sesi 4 . Setelah mengevaluasi dilanjutkan strategi pelaksanaan 5 yaitu mengontrol halusinasi dengan patuh obat. Disini peneliti dibantu oleh enumerator menjelaskan kepada subjek mengenai patuh obat sesuai dengan resep yang sudah ditentukan dokter penanggung jawab. Setelah dijelaskan subjek dapat memahami patuh obat, yaitu tepat jenis, jumlah, waktu, cara dan manfaat dari masing-masing obat.
Observasi hari 6, pada sesi ini peneliti mengulang dari strategi pelaksanaan 1 sampai 5 untuk mengetahui kemampuan subjek dalam menerapkannya apakah perlu diulangi atau sudah cukup. Setelah peneliti mengulangi komunikasi terapeutik sampai selesai subjek mampu menerapkannya dan mampu menjelaskan kembali apa yang sudah dijelaskan. Kemudian peneliti akan melakukan evaluasi perkembangan kemampuan subjek dalam mengontrol halusinasi pada sesi ke 7 .

Observasi hari terakhir setelah 6 hari dilakukan penerapan komunikasi terapeutik, diperoleh hasil subjek dapat mengontrol halusinasinya setelah dilakukan komunikasi terapeutik dengan strategi pelaksanaan per sesi sesuai dengan SOP, serta mengerti tahapan melakukannya dan lembar observasi harian serta wawancara post-test sebagai evaluasi menunjukkan terdapat peningkatan kemampuan mengontrol halusinasi subjek untuk mengurangi frekuensi munculnya halusinasi .

Tabel 6. Hasil Observasi Harian Subjek II

\begin{tabular}{|c|c|c|c|c|c|c|c|c|}
\hline \multirow{2}{*}{ No } & \multirow{2}{*}{ Kemampuan } & \multicolumn{7}{|c|}{ Hari } \\
\hline & & 1 & 2 & 3 & 4 & 5 & 6 & 7 \\
\hline 1 & $\begin{array}{l}\text { Mengenal } \\
\text { jenis } \\
\text { halusinasi }\end{array}$ & $x$ & $\checkmark$ & $\checkmark$ & $\checkmark$ & $\checkmark$ & $\checkmark$ & $\checkmark$ \\
\hline 2 & $\begin{array}{l}\text { Mengenal isi } \\
\text { halusinasi }\end{array}$ & $x$ & $\checkmark$ & $\checkmark$ & $\checkmark$ & $\checkmark$ & $\checkmark$ & $\checkmark$ \\
\hline 3 & $\begin{array}{l}\text { Mengenal } \\
\text { waktu } \\
\text { halusinasi }\end{array}$ & $x$ & $\checkmark$ & $\checkmark$ & $\checkmark$ & $\checkmark$ & $\checkmark$ & $\checkmark$ \\
\hline 4 & $\begin{array}{l}\text { Mengenal } \\
\text { frekuensi } \\
\text { halusinasi }\end{array}$ & $x$ & $\checkmark$ & $\checkmark$ & $\checkmark$ & $\checkmark$ & $\checkmark$ & $\checkmark$ \\
\hline 5 & $\begin{array}{l}\text { Mengenal } \\
\text { situasi yang } \\
\text { menimbulkan } \\
\text { halusinasi }\end{array}$ & $x$ & $\checkmark$ & $\checkmark$ & $\checkmark$ & $\checkmark$ & $\checkmark$ & $\checkmark$ \\
\hline 6 & $\begin{array}{l}\text { Menjelaskan } \\
\text { respon } \\
\text { terhadap } \\
\text { halusinasi }\end{array}$ & $x$ & $x$ & $\checkmark$ & $\checkmark$ & $\checkmark$ & $\checkmark$ & $\checkmark$ \\
\hline 7 & $\begin{array}{l}\text { Mampu } \\
\text { menghardik } \\
\text { halusinasi }\end{array}$ & $x$ & $x$ & $\checkmark$ & $\checkmark$ & $\checkmark$ & $\checkmark$ & $\checkmark$ \\
\hline
\end{tabular}




\begin{tabular}{|c|l|c|c|c|c|c|c|c|}
\hline 8 & $\begin{array}{l}\text { Mampu } \\
\text { bercakap- } \\
\text { cakap jika } \\
\text { terjadi } \\
\text { halusinasi }\end{array}$ & $\times$ & $\times$ & $\times$ & $\checkmark$ & $\checkmark$ & $\checkmark$ & $\checkmark$ \\
\hline 9 & $\begin{array}{l}\text { Membuat } \\
\text { jadwal } \\
\text { kegiatan } \\
\text { harian }\end{array}$ & $\times$ & $\times$ & $\times$ & $\times$ & $\checkmark$ & $\checkmark$ & $\checkmark$ \\
\hline 10 & $\begin{array}{l}\text { Melakukan } \\
\text { kegiatan } \\
\text { harian sesuai } \\
\text { jadwal }\end{array}$ & $\times$ & $\times$ & $\times$ & $\times$ & $\times$ & $\checkmark$ & $\checkmark$ \\
\hline 11 & $\begin{array}{l}\text { Menggunakan } \\
\text { obat secara } \\
\text { teratur }\end{array}$ & $\checkmark$ & $\checkmark$ & $\checkmark$ & $\checkmark$ & $\checkmark$ & $\checkmark$ & $\checkmark$ \\
\hline
\end{tabular}

Observasi hari 1, subjek II kurang bisa menjawab atau menjelaskan masalahnya dengan pertanyaan apa, di mana, kapan, siapa, dan bagaimana. Selain itu subjek juga tampak adanya kontak mata. Kemudian didapatkan hasil pikiran otomatis subjek 1 adalah subjek tidak yakin bahwa subjek berhalusinasi dan tidak mengetahui jenis serta waktu munculnya halusinasi.

Observasi Hari 2, diperoleh subjek dapat mengutarakan sedikit-sedikit jenis, isi, frekuensi halusinasinya, yaitu mengidentifikasi halusinasi yang dialami subjek. Kemudian subjek dapat menyebutkan jenis halusinasinya yaitu halusinasi penglihatan seperti merasa rambutnya ditariktarik, subjek belum mengetahui frekuensi muncul halusinasi. Kemudian peneliti belum bisa melanjutkan pada strategi pelaksanaan II karena subjek masih kurang dapat mengidentifikasi halusinasinya. Pada sesi 2 ini peneliti mengulangi kembali strategi pelaksanaan I yaitu tentang mengontrol halusinasi dengan cara menghardik. Pada sebelumnya saat pre-test subjek mengaku lupa apa itu menghardik, sehingga peneliti menjelaskan kembali pengertian dan cara-cara menghardik. Subjek dapat memahami dan mampu menirukan atau mengulangi cara-cara yang sudah diajarkan, subjek juga mengutarakan perasaan senangnya. Peneliti menulis peningkatan kemampuan subjek tersebut dan membuat rencana tindak lanjut latihan menghardik untuk di evaluasi pada sesi berikutnya.
Observasi hari 3, peneliti melanjutkan strategi pelaksanaan II yaitu tentang mengontrol halusinasi dengan cara menghardik. Peneliti menjelaskan ke pengertian dan cara-cara menghardik. Subjek dapat memahami dan mampu menirukan atau mengulangi cara-cara yang sudah diajarkan. Peneliti menulis peningkatan kemampuan subjek tersebut dan membuat rencana tindak lanjut latihan menghardik untuk di evaluasi pada sesi berikutnya dalam mengontrol halusinasi dan melanjutkan strategi pelaksanaan III yaitu mengontrol halusinasi dengan bercakap-cakap bersama teman-teman subjek.

Observasi hari 4, pada evaluasi menghardik subjek mengatakan sudah mampu menerapkannya saat halusinasi muncul. Kemudian dilanjutkan Strategi pelaksanaan III, setelah dilakukan sesi bercakap-cakap subjek bersama temannya diperoleh subjek dapat berdiskusi serta mampu memulai atau mengawali pembicaraan. Kemudian subjek dapat mengungkapkan keinginannya bahwa subjek ingin berinteraksi bersama siapapun tanpa ada batasan. Kemudian subjek dikenalkan metode membuat jadwal mengisi waktu luang atau kegiatan harian dan akan dibahas pada sesi berikutnya .

Observasi hari 5, peneliti menanyakan bagaimana perkembangan bercakap-cakap bersama teman subjek mengatakan sudah menerapkan dengan baik. Kemudian selanjutnya dilakukannya strategi pelaksanaan 4 bersama subjek diperoleh subjek dapat membuat jadwal kegiatan seharihari untuk dijadikan sebagai aktivitas sehingga halusinasi dapat terkontrol.

Observasi hari 6, ini peneliti mengevaluasi aktivitas subjek sudah sesuai dengan jadwal yang dibuat pada sesi 5 . Setelah mengevaluasi dilanjutkan strategi pelaksanaan 5 yaitu mengontrol halusinasi dengan patuh obat. Di sini peneliti menjelaskan kepada subjek mengenai patuh obat sesuai dengan resep yang sudah ditentukan dokter penanggung jawab. Setelah dijelaskan subjek dapat memahami patuh obat, yaitu tepat jenis, jumlah, waktu, cara dan manfaat dari masing-masing obat.. 
Observasi hari terakhir setelah 6 hari penerapan komunikasi terapeutik, peneliti mengulang dari strategi pelaksanaan 1 sampai 5 untuk mengetahui kemampuan subjek dalam menerapkannya apakah perlu diulangi atau sudah cukup. Setelah peneliti mengulangi komunikasi terapeutik sampai selesai subjek mampu menerapkannya dan mampu menjelaskan kembali apa yang sudah dijelaskan. Kemudian peneliti akan melakukan evaluasi perkembangan kemampuan subjek dalam mengontrol halusinasi setelah dilakukan komunikasi terapeutik dengan strategi pelaksanaan per sesi sesuai dengan SOP, serta mengerti tahapan melakukannya dan lembar observasi harian serta wawancara post-test sebagai evaluasi menunjukkan terdapat peningkatan kemampuan mengontrol halusinasi subjek untuk mengurangi frekuensi munculnya halusinasi .

Pada tabel observasi kedua subjek, dapat disimpulkan bahwa adanya perbedaan kemajuan pada subjek dalam mengontrol halusinasi. Hal ini tampak pada observasi hari pertama subjek I dapat memahami dan mengikuti pelaksanaan komunikasi terapeutik dengan lancar, untuk subjek II mengalami hambatan.

\section{PEMBAHASAN}

Berdasarkan hasil penelitian, setelah dilakukan penerapan komunikasi terapeutik selama 6 (enam) hari dapat disimpulkan bahwa kedua subjek mampu mengontrol halusinasinya, tetapi ada perbedaan kemajuan dalam mengontrol halusinasi pada subjek I dan II.

Hal tersebut sesuai dengan hasil penelitian yang menyatakan bahwa komunikasi terapeutik dapat menurunkan frekuensi kekambuhan pada pasien halusinasi dikarenakan semakin banyak klien tersebut mendapat terapi pengobatan dan perawatan dengan baik, sehingga klien dapat mampu mengontrol halusinasi yang dialaminya dan menjadi lebih baik dikemudian hari (Astutik, 2018). Penelitian lain menyatakan bahwa komunikasi terapeutik yang dilakukan sesuai tahapan dengan tepat akan membantu pasien untuk mengontrol halusinasinya (Sulahyuningsih et al., 2016).

Halusinasi merupakan keadaan hilangnya kemampuan individu dalam membedakan rangsangan internal (pikiran) dan rangsangan eksternal (dunia luar). Klien memberi persepsi atau pendapat tentang lingkungan tanpa objek atau rangsangan yang nyata. Sebagai contoh klien mengatakan mendengar suara padahal tidak ada orang yang berbicara. Gejala gangguan jiwa dimana klien mengalami perubahan persepsi sensori: merasakan sensori palsu berupa suara, penglihatan, pengecapan atau penghiduan (Yusuf et al., 2015).

Menurut peneliti gangguan persepsi sensori halusinasi pendengaran dipengaruhi oleh beberapa faktor salah satu yang terjadi pada subjek I adalah faktor presipitasi dimensi emosional dan dimensi spiritual sangat berkaitan di mana kondisi emosional yang tidak stabil pada saat subjek di tinggal sama adiknya sehingga subjek merasa tertekan dengan perintah saudaranya. Kondisi spiritual yang mempengaruhi adalah di saat subjek tidak mau beribadah dan meyakini dirinya seorang Nabi dan orang lain harus patuh dengan perintahnya sehingga subjek melihat orang lain adalah setan yang harus taat kepadanya. Sedangkan pada subjek II adalah faktor sosiokultural dan psikologis sangat berkaitan di mana hubungan interpersonal yang tidak harmonis pada saat subjek di rumah dan mendapatkan tekanan dari kedua orang tuanya untuk giat belajar agar pintar seperti saudaranya sehingga subjek merasa dirinya tidak mampu dan tidak bisa disamakan dengan saudaranya. Faktor presipitasi yang mempengaruhi adalah kondisi di mana subjek menarik diri menyebabkan klien mengingat tekanan dari orang tua yang membuat subjek menjadi diam dan tidak mau berbicara dengan orang lain sehingga klien mengalami halusinasi.

Subjek I merupakan anak kedua dari empat bersaudara, subjek sebelumnya tinggal bersama suaminya dan ke empat anaknya. Kemudian subjek tinggal bersama adiknya karena dekat dari RS Jiwa Menur agar lebih mudah kontrol dan ada yang mengawasinya. 
Subjek mengatakan perannya sebagai ibu rumah tangga dan sebagai kakak untuk adiknya, subjek merasa bersalah karena sudah bersikap yang buruk dan tidak memberi contoh yang baik, bagi subjek orang yang sangat berarti adalah anak-anaknya. Dari hasil observasi, cara berpakaian subjek sesuai dan rapi, rambut rapi. Saat berinteraksi subjek bicara dengan lancar, suara keras tidak gagap dan klien mampu memulai pembicaraan serta kooperatif. Subjek mengalami persepsi penglihatan yang berupa isi: subjek melihat orang lain seperti setan atau monster yang harus patuh kepada subjek karena subjek menganggap dirinya seorang Nabi dan mendengarkan bisikan yang menyuruh subjek untuk wiritan terus agar tidak mati. Subjek kadang-kadang bicara sendiri, frekuensi: kadang-kadang, waktu: tidak menentu dan secara tiba-tiba, proses pikir klien baik yaitu saat interaksi tidak berbelit- belit dan langsung ke topik dan tujuan yang dibicarakan dengan perawat. Klien mengatakan kurang pengetahuan tentang, faktor prespitasi, koping, sistem pendukung, penyakit fisik, sehingga klien kurang mengetahui cara yang tepat untuk mengatasi masalah tersebut.

Sedangkan pada Subjek II merupakan anak pertama dari tiga bersaudara, subjek tinggal bersama ibu dan adiknya. Subjek mengatakan perannya sebagai anak sudah salah, subjek merasa berdosa dan bersalah karena sudah mengamuk kepada ibunya jika dipaksa minum obat, dan sering teriak-teriak kesakitan sehingga tetangga ketakutan, bagi subjek orang yang sangat berarti adalah ibunya. Dari hasil observasi, cara berpakaian klien sesuai dan rapi, rambut rapi. Saat berinteraksi subjek bicara dengan lancar, suara kecil sedikit gagap dan subjek tidak bisa memulai pembicaraan dan kurang kooperatif. Subjek mengalami persepsi pendengaran yang berupa isi: subjek mendengarkan bisikan yang menyuruh subjek untuk belajar terus menulis tidak boleh berhenti, subjek kadang- kadang teriak kesakitan karena merasa ada orang menarik rambutnya, frekuensi: sering, waktu: di saat subjek melamun dan tidur secara tibatiba, proses pikir subjek kurang baik yaitu saat interaksi berbelit-belit dan kurang mampu mengungkapkan yang dirasakan kepada perawat. Subjek mengatakan kurang pengetahuan tentang penyakit jiwa, koping, sistem pendukung, dan obat-obatan sehingga klien tidak mengetahui cara yang tepat untuk mengatasi masalah tersebut.

Menurut (Muhith, 2015) penyebab terjadinya halusinasi merupakan biologis dimana abnormalitas perkembangan sistem saraf yang berhubungan dengan respon neurobiologis yang maladatif baru mulai dipahami. Ini menunjukkan penelitian pencitraan otak sudah menunjukkan keterlibatan otak yang lebih luas dalam perkembangan skizofrenia. Lesi pada daerah frontal, temporal dan limbik berhubungan dengan perilaku psikotik. Psikologis merupakan lingkungan klien yang sangat mempengaruhi respon dan kondisi psikologis klien. Pada klien gangguan persepsi sensori pada pemeriksaan fisik terdapat pengkajian psikososial yang meliputi: genogram untuk mengetahui kemungkinan adanya riwayat genetik yang menyebabkan atau menurunkan gangguan jiwa, konsep diri yaitu pada citra tubuh, bagaimana persepsi klien terhadap tubuhnya yang paling atau tidak disukai, identitas diri bagaimana persepsi tentang status dan posisi klien, kepuasan klien terhadap suatu posisi tersebut, kepuasan klien sebagai laki-laki atau perempuan, peran bagaimana harapan klien terhadap tubuhnya, posisi, status, tugas atau peran yang diharapannya dalam keluarga, kelompok, masyarakat, dan bagaimana kemampuan klien dalam melaksanakan tugas atau peran tersebut. Ideal diri bagaimana harapan klien terhadap tubuhnya, posisi, status, tugas/peran dan harapan klien terhadap lingkungan (Debora, 2011) . Observasi penampilan umum klien yaitu penampilan usia, cara berpakaian, kebersihan, sikap tubuh, cara berjalan, ekspresi wajah, kontak mata, bagaimana pembicaraan yang didapatkan pada klien, apakah cepat, keras, gagap, inkhoheren, apatis, lambat, membisu seperti aktivitas motorik berkenaan dengan gerakan titik perlu dicatat dalam hal tingkat aktivitas (latergik, tegang, gelisah, agitasi), jenis (TIK, tremor) dan isyarat tubuh yang tidak wajar. 
Merupakan nada perasaan yang menyenangkan atau tidak menyenangkan yang menyertai suatu pikiran dan langsung relatif lama dengan sedikit komponen fisiologis serta bangga, kecewa. Emosi merupakan manifestasi afek yang ditampilkan atau diekspresikan keluar, disertai banyak komponen fisiologis dan berlangsung relatif lebih singkat atau spontan seperti sedih, ketakutan, putus asa, gelisah atau gembira berlebihan (Diah, 2013)

Menurut penulis klien dengan gangguan persepsi sensori halusinasi pendengaran salah satunya akan mengalami gelisah, ngomel-ngomel sendiri, mendengar suara/bisikan yang memberikan persepsi atau pendapat tentang lingkungan tanpa ada objek atau rangsangan yang nyata.

Berdasarkan hasil di atas penelitian ini sejalan dengan teori menurut (Afnuhazi, 2015), manusia sebagai makhluk holistik dipengaruhi oleh lingkungan dalam dirinya dan lingkungan dari luar, baik keluarga, kelompok maupun komunitas. Dalam berhubungan dengan lingkungan, manusia harus mengembangkan strategi koping yang efektif agar dapat beradaptasi. Lingkungan interaksi akan mempengaruhi komunikasi yang efektif, suasana yang bising, tidak ada privasi yang tepat akan menimbulkan ketegangan dan ketidaknyamanan.

Komunikasi terapeutik dalam penelitian ini dilakukan sebanyak 6 kali dalam seminggu, satu hari selama 15-30 menit setiap satu kali pertemuan. Komunikasi terapeutik pada penelitian ini menggunakan tahapan strategi pelaksanaan halusinasi di mana untuk 1 kali perlakuan SP dilakukan 1 kali dalam 1 hari. Tujuan dari penelitian ini melihat ada pengaruh tahapan strategi pelaksanaan komunikasi terapeutik pada pasien halusinasi. Untuk berkomunikasi dengan klien halusinasi sebaiknya bersikap tenang, bicara lembut, bicara tidak dengan cara menghakimi, bicara netral dan dengan cara konkrit, tunjukkan rasa hormat, kontak mata langsung, demonstrasikan cara mengontrol halusinasi, fasilitasi pembicaraan klien dan dengarkan klien, jangan terburu-buru menginterpretasikan dan jangan buat janji yang tidak bisa ditepati. Hal ini diperkuat dengan penelitian (Azizah et al., 2013) membuktikan bahwa komunikasi terapeutik adalah hubungan antara perawat dan pasien dalam proses komunikasi perilaku orang lain yang tujuannnya merubah perilaku dalam pencapaian kesehatan yang optimal. Namun dalam melakukan komunikasi terapeutik ini perawat memiliki kendala dalam melakukan komunikasi yang sifatnya terapeutik, salah satu kendala yang paling sering dijumpai pada saat melakukan komunikasi kepada pasien yang mengalami halusinasi adalah pada saat halusinasi pasien lebih dominan menguasai diri pasien dan pada akhirnya konsentrasi pasien terpecah, dan pasien pun sulit mendapatkan informasi yang di berikan oleh perawat. Menurut (Stuart, 2013) menyatakan bahwa komunikasi terapeutik merupakan hubungan interpersonal antara perawat dengan pasien, dalam hubungan ini perawat dan klien memperoleh pengalaman belajar bersama dalam rangka memperbaiki kondisi psikologis atau kejiwaan pasien. Dengan demikian hubungan terapeutik merupakan suatu hubungan yang bersifat kerja sama yang bersifat terapeutik yang ditandai adanya pertukaran perilaku, perasaan, pikiran dan pengalaman dalam membina hubungan saling percaya.

Setelah dilakukan penerapan komunikasi terapeutik selama 6 kali pertemuan yang dilakukan peneliti sesuai dengan Standar Operasional Prosedur (SOP) terhadap kedua subjek gangguan persepsi sensori halusinasi dengan latar belakang permasalahan berbeda menunjukan adanya kemajuan kemampuan dalam mengontrol halusinasinya yang dapat dibuktikan dengan hasil wawancara, hasil observasi dan tahap pelaksanaannya. Jadi dapat disimpulkan bahwa komunikasi terapeutik dapat meningkatkan hubungan perawat dengan klien dan bisa membantu pasien untuk mengontrol halusinasinya sehingga dapat mengurangi frekuensi munculnya halusinasi.

Berdasarkan uraian di atas dapat disimpulkan bahwa adanya pengaruh tahapan strategi pelaksanaan komunikasi terapeutik pada pasien halusinasi hal ini dikarenakan 
komunikasi terapeutik dapat meningkatkan interaksi antara perawat dengan pasien. Di mana perawat bisa menjadi teman pasien untuk berbagai cerita tentang permasalahan yang dihadapi pasien sehingga secara tidak langsung pasien memiliki ikatan emosional dengan perawat. Hal ini bisa menjadi salah satu cara untuk membantu pasien dalam mengontrol halusinasi yang dialaminya sehingga dapat menurunkan frekuensi munculnya halusinasi. Dan diharapkan perawat untuk dapat lebih meningkatkan komunikasi terapeutik agar dapat dilaksanakan secara terus menerus supaya pasien dengan gangguan persepsi halusinasi dapat meningkatkan kemampuannya dalam mengontrol halusinasi serta mengalami perubahan perilaku maupun sikap yang lebih baik (adaptif).

\section{KESIMPULAN}

Sebelum dilakukan komunikasi terapeutik untuk mengetahui kemampuan pasien skizofrenia dalam mengontrol halusinasi didapatkan pada Subjek I mengalami halusinasi dengan penglihatan dan pendengaran hal ini dipengaruhi karena waham kebesaran (subjek merasa dirinya adalah Nabi) dengan waham tersebut muncul halusinasi subjek yang berlebihan dan tidak terkontrol dan pada Subjek II memiliki halusinasi pendengaran hal ini dipengaruhi karena subjek harga diri rendah. Kebiasaan menyendiri dengan pengalaman masa lalu subjek yang menyebabkan timbulnya halusinasi pendengaran selain itu ketidak rutinan subjek mengkonsumsi obat membuatnya sering kambuh.

Setelah dilakukan pendekatan dengan komunikasi terapeutik dengan frekuensi 1 kali sehari selama 6 (enam) hari, Subjek I dan II mengalami peningkatan kemampuan dalam mengenali dan mengontrol halusinasinya.

\section{UCAPAN TERIMA KASIH}

Penelitian ini dapat terlaksana oleh penulis dengan mendapatkan banyak pengarahan dan bantuan dari berbagai pihak, untuk itu dalam kesempatan ini penulis dengan rendah hati mengucapkan terima kasih yang sebesar-besarnya semua pihak yang tidak dapat penulis sebutkan satu persatu yang telah membantu penulis dalam menyelesaikan penelitian dan artikel ini.

\section{DAFTAR PUSTAKA}

Afnuhazi, R. (2015). Komunikasi terapeutik dalam keperawatan jiwa. Yogyakarta: Gosyen Publishing.

Astutik, I. (2018). Pengaruh Komunikasi Terapeutik Terhadap Frekuensi Kekambuhan Pada Pasien Halusinasi Di Ruang Ipcu Mawar Rsj Dr Radjiman Wediodiningrat Lawang Malang. Skripsi Keperawatan, O(0), Article http://103.38.103.27/repository/index. php/S1-KEP/article/view/1097

Azizah, S., Lestari, P., \& Novitasari, L. (2013). Pengaruh Komunikasi Terapeutik Terhadap Kecemasan Lansia yang Tinggal Di Balai Rehabilitasi Sosial "Mandiri" Pucang Gading Semarang. Jurnal Keperawatan Jiwa, 1(1).

Debora, O. (2011). Proses Keperawatan dan Pemeriksaan Fisik. Salemba Medika.

Diah, N. K. (2013). Studi Kasus Asuhan Keperawatan Pada Klien Gangguan Persepsi Sensori Halusinasi Pendengaran. Surakarta.

Direja, A. H. S. (2011). Buku Ajar Asuhan Keperawatan Jiwa (1st ed.). Nuha Medika.

Keliat, B. A., \& Prawirowiyono, A. (2016). Keperawatan jiwa: Terapi Aktivitas Kelompok (2nd ed.). EGC.

Kemenkes RI. (n.d.). Laporan Riset Kesehatan Dasar (Riskesdas) 2018. Retrieved August 6, 2020, from http://archive.org/details/LaporanRisk esdas2018NasionalPromkes.net 
NERS: Jurnal Keperawatan, Volume 16, No. 2, Oktober 2020, (Hal. 61-74)

Muhith, A. (2015). Pendidikan Keperawatan Jiwa: Teori dan Aplikasi (1st ed.). Penerbit Andi.

Stuart, G. W. (2013). Principles and practice of psychiatric nursing (10th ed). Elsevier Saunders.

Stuart, G. W., \& Laraia, M. T. (Eds.). (2001). Principles and practice of psychiatric nursing (7th ed). Mosby.

Sulahyuningsih, E., Arum Pratiwi, S. K., \& Sahuri Teguh, S. K. (2016). Pengalaman Perawat Dalam Mengimplementasikan Strategi Pelaksanaan (SP) Tindakan Keperawatan Pada Pasien Halusinasi di Rumah Sakit Jiwa Daerah Surakarta [S1, Universitas Muhammadiyah Surakarta]. https://doi.org/10/6.\%20BAB\%20III. pdf

Yusuf, A., PK, R. F., \& Nihayati, H. E. (2015). Buku Ajar Keperawatan Kesehatan Jiwa. Salemba Medika. https://www.academia.edu/33133206/ Buku_Ajar_Keperawatan_Kesehatan Jiwa 